\title{
Juvenile Hormone Breaks Ovarian Diapause in Two Nymphalide Butterflies
}

The peacock Inachis io [=Vanessa io] and the tortoiseshell Aglais urticae [=Vanessa urticae $]$ feed on nettles during their larval instars. In northern Switzerland Inachis produces usually 2, Aglais 2-3 gererations per year $^{1}$. The ovaries of freshly eclosed females are little developed and thus belong to the postmetabolic type ${ }^{2}$.

Adults of the autumn generation enter reproductive diapause. Although the butterflies feed and fly quite actively till late in autumn, they will not mate until after hibernation. The accessory glands of both sexes and the ovaries of the females are inactive and remain at the developmental stage of the freshly eclosed insect. Development of the oocytes is arrested at an early previtellogenic stage and the tiny egg chambers fill only the apical third of the small ovarioles.

A similar type of reproductive diapause is found in adult $A$. urticae and $I$. io reared in the laboratory from field collected caterpillars. Regardless of wheter the larvae belong to the spring or late summer generation the adults will not mate in captivity. When kept in sun exposed flying-cages $(60 \times 60 \times 50 \mathrm{~cm})$, furnished with sugar water in artificial flowers and a fresh bouquet of nettles for oviposition, the butterflies will drink and may live for several months, but the ovaries and accessory glands of the females do not develop further than in freshly eclosed insects; vitellogenesis never takes place.

Except for Pievis brassicae vitellogenesis has not been studied in rhopalocerous Lepidoptera. In this species it depends on the presence of juvenile hormone $(\mathrm{JH})$, which is produced in the corpora allata $(\mathrm{CA})^{3-7}$. These glands are activated by mating and nutrition ${ }^{6}$. Topical application of synthetic JH-mimetics induces vitellogenesis in virgin females which lack $\mathrm{CA}^{5,7}$ and may hasten oogenesis and oviposition in mated females. It was therefore thought that the developmental standstill of the nymphalide ovary in caged and naturally diapausing females might indicate that their CA are inactive and that the same condition might be responsible for the sexual inactivity of caged and diapausing males. $1 \mathrm{t}$ is known that sexual activity of the males of some orthopterous species depends on the activity of the CA ${ }^{9-12}$.

In order to test these hypotheses males and females of $A$. urticae and females of $I$. io were treated topically with $1 \mu l$ of $10 \%$ acetone solution of either farnesenic acid ethyl ester or the all-cis/trans-mixture of isomeres of the JH methyl 10,11 epoxy-7-ethyl-3,11-dimethyl-2,6-tridecadienoate $^{13}$, both substances furnished by Hoffmann-La Roche Ltd. Basle. Females were sacrificed and dissected at 3,5 , and 10 days after treatment.

In the females of both species the two substances induced swelling of the accessory glands and maturation of 120-150 eggs within 3 days. The ovaries were filled with 180-250 mature eggs at 5 and 10 days after treatment. Copulations have not been observed and none of the females contained a spermatophore or laid eggs.
The results verify the hypothesis that the diapause of the ovaries and the accessory glands in Aglais and Inachis females is a consequence of the inactivity of the $\mathrm{CA}$ which fail to produce the JH. Mating and oviposition on the other hand are not stimulated by this hormone. These findings agree with observations on Pieris ${ }^{6}$. Sexual inactivity of caged nymphalides, and probably also of naturally diapausing butterflies, is thus not merely a consequence of inactivity of the CA. It has been reported that in nature the males of these species follow a female in the afternoon and, after a long nuptual flight, mate in the evening, when the female goes to rest for the night ${ }^{14}$. This ritual is probably necessary for copulation and cannot take place in captivity.

Since JH-treated virgin females containing large numbers of mature eggs did not oviposit in the presence of their host plant, it seems likely that in these species the basic stimulus for oviposition is furnished by mating and impregnation as in many other Lepidoptera, e.g. Pieris ${ }^{6}$ and the tortricide Zeiraphera diniana ${ }^{15}$.

Zusammentassung. Falter des Tagpfauenauges Inachis io und des kleinen Fuchses Aglais urticae fallen in der Natur im Herbst, in Gefangenschaft aber zu jeder Jahreszeit in reproduktive Diapause. Die Diapause der Ovarien und der Kittdrüsen der Weibchen kann jederzeit durch topicale Behandlung mit synthetischen Juvenilhormonderivaten gebrochen werden. Kopulation und Oviposition gefangener Falter werden jedoch durch das Hormon nicht stimuliert.

G. BENZ

Department of Entomology,

Swiss Federal Institute of Technology,

CH-8006 Zürich (Switzerland), 24 April 1972.

1 M. STANDFuss, Handbuch der paläarktischen Gross-Schmetterlinge (Fischer, Jena 1896).

2 H. Eidmann, Z. angew. Entomol. 18,57 (1931).

3 A. Karlinsky, C. 1. Acad. Sci., Paris 256, 4101 (1963).

4 A. Karuinsky, C. r. Acad. Sci., Paris 264, 1735 (1967).

5 A. Karlinskx, Proc. XIII Int. Cong. Entomol., Moscow 1968, 1, 393 (1971).

' G. BENz, in L'Influence des Stimuli Externes sur la Gamétogenèse des Insectes (Editions Centre Natl. Rech. Sci., Paris 189, 175 (1970)). 7 G. BENz, Experientia 26, 1012 (1970).

${ }^{8}$ G. BENz, Experientia 27, 581 (1971).

9 W. Loher, Proc. R. Soc., Lond. B 753, 380 (1960).

10 A. Girardie and A. Vogel, C. r. Acad. Sci., Paris 263, 543 (1966). 11 M. P. Pener, J. Insect. Physiol. 13, 665 (1967).

12 M. P. PENER, Entomologia exp. appl. 11, 94 (1968).

13 H. Roeller, K. M. Dahm, C. C. Sweeley and B. M. Trost, Angew. Chem. 6, 179 (1967).

14 R. R. BAKer, J. Animal Ecol. 47, 453 (1972).

${ }_{15}$ G. BenZ, J. Insect Physiol. 15, 55 (1969).

\section{Caryotypes de quelques hybrides interspécifiques de Pitymys (Mammalia, Rodentia)}

Bien que la taxonomie des Microtidés pose de nombreux problèmes, peu d'auteurs ont tenté de connaître les relations phylétiques des diverses formes par des essais de croisements entre espèces ou sous-espèces ${ }^{1}$, méthode encore récemment préconisée par PeTTER ${ }^{2}$. Les campagnols européens du genre Pitymys McMurtie montrent une grande diversité de caryotypes (Tableau I), mais ils sont souvent très difficilement identifiables morphologiquement. Il m'a paru intéressant d'essayer d'hybrider 3 espèces dont de nombreux spécimens ont été obtenus au cours de ces dernières années et qui se reproduisent facilement en captivité: $P$. multiplex (Fatio), P. subterraneus (de Sélys-Longchamps) et $P$. duodecimcostatus (de SélysLongchamps). La description des caryotypes de ces espèces 